\title{
The Art of Political Manipulation in the European Convention
}

\author{
GEORGE TSEBELIS \\ University of California, Los Angeles \\ SVEN-OLIVER PROKSCH \\ University of California, Los Angeles
}

\begin{abstract}
We argue that the success of the European Convention in producing a Constitutional Treaty was possible because of the agenda control exercised by the Praesidium and in particular its President. Given that even Intergovernmental Conferences despite months of preparations sometimes fail to produce any results, the failure of negotiations in the Convention was a distinct possibility. Another serious possibility would have been an 'anarchic' document, in which different parts would have reflected the prevalence of different majorities. The President of the Convention was able to avoid both of these possibilities. Our argument is that Giscard d'Estaing was able to produce the results through the astute use of three significant tools that he developed. First, he limited the number of amendments from Convention delegates by imposing time limits on the whole process. Second, he created an iterated agenda-setting process in order to modify amendments. Third, he prohibited voting, and produced results 'by consensus', defining the meaning of the term himself. Understanding that the European Convention was an exceptional event made possible by the combination of a creative, consistent and overpowering agenda-setting process as well as the impasse created by the status quo (Nice Treaty) explains how we came to the EU Constitutional Treaty and how difficult it will be to move away from this document.
\end{abstract}




\section{Introduction}

In the history of the EU there have been several summits that ended without results. ${ }^{1}$ Even during the most recent IGC, the meeting in Rome (2003) led to strong disagreements between the governments of EU Member States, thus delaying the adoption of a European Constitutional Treaty. Given the composition of the European Convention, which drafted the Constitutional Treaty, the likelihood of complete failure was significantly higher than at an Intergovernmental Conference. Instead, the Convention produced a Constitutional Treaty that included a simplification of the voting rules in the Council of Ministers, the creation of a Minister for Foreign Affairs and a permanent President of the European Council, as well as a definition of the competences (exclusive, shared and supporting) and their distribution between Member States and the EU. ${ }^{2}$ The reader may think that the document was in fact too advanced, because it got slightly modified in the IGC, and subsequently was rejected by referendums in two Member States (France and the Netherlands). Still, what remains to be explained is how the success of the European Convention was possible.

The European constitutional convention, simply called the European Convention, was convened in 2002 in order to revise and consolidate existing European treaties, which have formed the constitutional framework of the European Union since its beginnings in 1957. The Convention was a departure from the traditional way of revising the EU treaties through Intergovernmental Conferences (IGCs) in which each country was endowed with veto powers over the final outcome. The IGC procedure had led to extreme outcomes in the Nice Treaty in 2000. The intense disagreements between large and small states were resolved by including provisions to the liking of each group with the result of creating institutions which were difficult to work with (Tsebelis and Yataganas, 2002). Therefore, governments decided to convene a Convention on the Future of Europe. According to the Laeken declaration, the task of this Convention was: 'to consider the key issues arising for the Union's future development and try to identify the various possible responses' (European Council, 2001). The governments also decided on the overall composition of the 105 -member Convention. It was dominated by members of national parliaments (56 members, including opposition and anti-EU parties) and representatives from Member State governments

\footnotetext{
${ }^{1}$ For example, the European Council failed to make a deal over the EU's long-term budget at the EU summit in June 2005.

${ }^{2}$ The distribution of competences between the EU and Member States existed in the previous European treaties, but was consolidated in favour of the EU in the draft constitution as the draft abolished Member State vetoes in a number of policy areas.
} 
themselves (28 members). Other members included a delegation from the European Parliament (16 members) and the European Commission (two members). Whereas each of these component groups chose their various representatives, the Presidency of the Convention was picked by the governments themselves. They appointed former French president Valéry Giscard d'Estaing as President and former Prime Ministers Giuliano Amato (Italy) and Jean-Luc Dehaene (Belgium) as Vice-Presidents.

We argue that this success was possible because of the agenda control exercised over the Convention by the Praesidium and in particular its President. We will distinguish between two actors with agenda-setting power in the European Convention, one individual actor and one collective actor. The individual actor with agenda-setting power was the President of the Convention Valéry Giscard d'Estaing. He was supported by two Vice-Presidents, Giuliano Amato and Jean-Luc Dehaene, who chaired the plenary sessions in his absence. Together, these three constituted the Presidency and controlled the agenda of the plenary session. The collective actor with agenda-setting power was the Praesidium of the Convention. The Praesidium included the three members of the Presidency and 12 other members of the Convention, representing the so-called component groups of the Convention (European Commission, European Parliament, national parliaments, European Council Presidency and candidate countries). Contrary to the Presidency, the Praesidium's primary role as an agenda-setter was in drafting proposals for the Constitutional Treaty, which were then presented to the Convention. In our analysis, we therefore distinguish between the Presidency and the Praesidium when we discuss agenda control.

Tsebelis (2005) demonstrated how the President of the Convention Valéry Giscard d'Estaing used exhaustively the institutional means provided to agenda-setters and was quite successful in shaping the institutional structure of the EU. Indeed, he applied a series of traditional agenda-setting tools like time constraints, restrictive rules and gatekeeping in order to promote his goals. As a result, he was able to have a high success rate on the institutional provisions of the policies of the EU (over 90 per cent of his proposals were accepted by the European Convention and over 75 per cent by the subsequent IGC). In addition, he argues that Giscard used three different ways of introducing proposals: through the Praesidium, the Secretariat of the Convention which he appointed and controlled, or even personally.

Here we are expanding in two different ways. First, we argue that Giscard not only used the available means of agenda control, but because of his ability to shape the institutions of the Convention, he also shaped particular tools that enabled him to do something extraordinary: to extract from the Convention 
everything that this collective player was willing and able to provide. Second, our analysis covers the entire constitutional document and not just the institutions. Our argument is that the body Giscard was presiding over was significantly more extreme in its composition than intergovernmental conferences. Indeed, besides governments, it also included EU institutions like the Parliament and the Commission, as well as representatives of national parliaments who were less in favour of European integration than their own governments. Given that even intergovernmental conferences despite months of preparations sometimes fail to produce any results, the failure of any agreement in the Convention was a distinct possibility. Another serious possibility would have been an 'anarchic' document, in which different parts would have reflected the prevalence of different majorities. Giscard was able to avoid both of these possibilities. Our argument is that he was able to produce these results through the astute use of three significant tools that he developed. First, he limited the number of amendments by imposing timing to the whole process. Second, he created an iterated agenda-setting process in order to modify amendments. Third, he prohibited voting, and produced results 'by consensus', with him defining the meaning of the term. We will discuss each one of these tools sequentially.

\section{Limiting the Number of Amendments}

According to the rules of procedure of the Convention, the decision-making process in the European Convention worked as follows: the Praesidium (including the Presidency) decided on the draft constitutional texts and submitted these proposals to the Convention. The members of the Convention then could propose amendments to the proposals. The Praesidium examined the amendments with the support of the Secretariat. It then decided which amendments to accept or to reject (the rules are listed in appendix B). This account demonstrates that agenda control had two important dimensions. First, and this is the conventional understanding of agenda-setting, agenda control relates to the location of the proposals in the political space. The agenda-setter picks the point from the set of alternatives that can beat the status quo (win-set) which maximizes his utility. Second, and this is our contribution, agenda control includes restrictive amendment rules. Contrary to many legislatures, the European Convention did not follow a closed rule process, in which proposals are put to an up or down vote on the floor. In fact, there are accounts of the European Convention that emphasize its deliberative nature (Magnette and Nicolaidis, 2004). Moreover, the notion of open and transparent discussions at the European Convention was at the very centre of 
the European Council decision to install a constitutional convention instead of another intergovernmental conference (IGC). ${ }^{3}$

The agenda-setter in the Convention relied on three methods to set restrictive amendment rules which resulted in limiting the number of amendments from the floor. First, the Presidency was able to eliminate amendments altogether. We show how the President summarized dissenting views and pointed out only some important amendments in his remarks. Second, the Praesidium and the Presidency took the unilateral decision to break up its constitutional draft proposal and propose the Constitutional Treaty in many sequences. This meant that some proposals were presented to the floor earlier than others. We provide evidence that the number of amendments declined with each sequence and that strategic considerations were part of this timing. Third, at the very end of the Convention, the Presidency made informal changes to the rules of procedure intended to reduce the number of amendments even more. In the following, we describe these restrictive amendment rules and their effects on agenda control.

\section{Eliminating Amendments}

The rules of procedure granted all members the right to propose amendments. Hence, in a formal sense, neither the Praesidium nor the Presidency were able to prevent members from writing an amendment. As a result, members of the Convention wrote several thousand amendments, either proposing changes themselves or endorsing an existing amendment. The rules, however, did not specify any procedure for how those amendments would be dealt with once proposed. The rules created a procedural loophole and the agenda-setting Praesidium and the Presidency gained sufficient leverage over which amendments to accept and which ones to reject.

The method of eliminating amendments was simply not to consider them. On the occasion of the first presentation of Praesidium drafts to the floor, President Giscard d'Estaing outlined his interpretation of the amendment process. His statements included the vague phrase that only 'the most enriching' amendments would be considered:

I wish that the Convention shows an open spirit of co-operation. For my part, I try to ensure various equilibriums. It is not the Praesidium which writes the Constitution, it is the Convention. The Praesidium provides the work basis. Yes, you can applaud me, I think this is good. Without a work

\footnotetext{
${ }^{3}$ The Laeken Declaration reads: 'In order to pave the way for the next Intergovernmental Conference as broadly and openly as possible, the European Council has decided to convene a Convention composed of the main parties involved in the debate on the future of the Union. In the light of the foregoing, it will be the task of that Convention to consider the key issues arising for the Union's future development and try to identify the various possible responses' (European Council, 2001).
} 
basis, the task would be impossible. You thus have the first work basis [...] You will discuss and undoubtedly propose modifications or amendments. The method could be as follows. I believe that we should not discuss anything today. We will stick to our agenda. It is necessary to give you time to examine these texts. You can then forward us suggestions, remarks or proposals for an amendment. This is not necessarily a matter of drafting. You could say, for example, that the order is inappropriate or that you think we put too much emphasis on a certain issue and not enough on another. Your proposals must reach us by the end of next week. [...] The Praesidium will go through them to see which modifications and improvements they include. The texts will then return to you in the form of a new proposal integrating the [amendment] proposals which appeared the most enriching.

Valéry Giscard d'Estaing, 6 February 2003, Plenary Session of the Convention (European Convention, 2003c)

Instead of guaranteeing that all amendments would be given equal consideration, this procedure ensured that the Praesidium could filter and thus eliminate amendments. As such, it was an important element of agenda control. The agenda-setter then was able to reduce the number of amendments that would receive serious consideration. After amendments had been proposed by the set deadline, the Praesidium and the Presidency published summaries of the received amendments, which were compiled by the Secretariat of the Convention. However, the members of the Convention did not have a guarantee that their amendments were adequately reflected in those summaries. Moreover, the summaries did not reveal any information as to which amendments would be accepted. It was the Praesidium chaired by President Giscard d'Estaing which decided behind closed doors which amendments to accept or not. The President then explained this decision to the floor. He presented a long list of issues and pointed out some individual amendments which had been proposed. Often, he did not mention the substance and content of other amendments. As a result, amendments were eliminated.

In the following, we illustrate this procedure with delegate statements from one Convention session (plenary session on 5 June 2003). All of them reflect the strong agenda control of the Praesidium and Presidency. The session dealt with proposed amendments on the first part of the draft Constitutional Treaty (excluding the rules on institutions). President Giscard d'Estaing opened the debate by describing the revised draft proposal of the Praesidium. We limit our illustration to three controversial issues mentioned in Giscard's intervention: the delimitation of competences, democratic life of the EU and the immediate environment of the EU. 
The section regarding competences was to clarify the powers and competences of the EU. It introduced a distinction between exclusive EU competences, shared competences and supporting competences intended to supplement actions taken by the Member States. The members of the Convention proposed a total of 613 amendments on these issues, around 10 per cent of all proposed amendments in the Convention. Giscard d'Estaing's comments, however, did not seem to reflect this number:

Regarding the competences of the Union, there are several amendments but finally fairly few. These are articles which are not subject to many amendments.

Valéry Giscard d'Estaing, 5 June 2003, Plenary Session of the Convention (European Convention, 2003c)

The section on democratic life in the Union included issues such as obligations on the institutions with regard to consultation of civil society, transparency, access to documents and respect for personal data. The Praesidium received a total of 335 amendments. One draft article by the Praesidium had proposed to have regular dialogue between the EU and churches and nonconfessional organisations. A large number of members of the Convention opposed this article and 15 amendments were proposed to delete it. The President seemed not to be impressed:

With regard to the democratic life of the Union, there are few amendments [...] There are several amendments to delete article 51 on the status of churches and non-confessional organisations, but these amendments are not numerous.

Valéry Giscard d'Estaing, 5 June 2003, Plenary Session of the Convention (European Convention, 2003c)

Our last example that demonstrates how the agenda-setter eliminated amendments deals with the proposed articles on the relationship between the EU and its neighbouring states as well as with EU membership criteria:

Concerning the issue of the Union and its immediate environment, which constitutes an innovation in our proposals, there are five amendments. This shows that the current draft text is largely accepted. Similarly, the issues of EU membership and suspension of Union membership rights seem to enjoy general agreement.

Valéry Giscard d'Estaing, 5 June 2003, Plenary Session of the Convention (European Convention, 2003c)

In short, while the President of the Convention was not able to prevent amendments to his proposals, he was able to limit their number. Because of the 
absence of clearly defined amendment rules, he was able to interpret the rules in a way that ensured that he could favour certain amendments over others.

\section{Timing of Proposals}

Some studies on the Convention emphasize the importance of the Presidency's decision to break up the work into three stages: a listening stage, a study stage and a drafting stage (Crum, 2004; Magnette and Nicolaidis, 2004). This was an important choice for two reasons. First, it limited the amendability of Praesidium proposals to the final stage. Second, it reduced the ability of proposers of amendments to persuade their peers. In addition, an important decision of the Praesidium and the President was to break up its proposal for a draft Constitutional Treaty into several sequences. ${ }^{4}$ Those sequences introduced the element of timing to agenda-setting. We suppose that members of the Convention preferred to discuss issues at the earliest point possible so that they would be able to examine the proposals thoroughly and prepare and submit their amendments. Because the agenda-setter controlled the timing of proposals, he was able to hold back significant proposals until the end when time was running out. This way, the later the proposal was made, the fewer amendments were proposed. Strategic timing therefore eliminated some amendments.

We examine our claim using the entire set of amendments and Praesidium proposals of the Convention. The Praesidium presented its proposals in 17 separate documents between February and May 2003. Together, these constitute the entire, initial Praesidium proposal for the constitution. Treating the documents themselves as the units of analysis is, however, problematic, because some of them were proposed on the same day and thus really constitute one particular sequence. Because our focus is on the timing of the proposals, we use the sequences as the unit of analysis. We therefore define a proposal sequence as the day on which the Praesidium presented proposals. This way, the 17 documents by the Praesidium collapse to ten proposal sequences. For each sequence, we code the date, the total number of amendments submitted by members of the Convention, the length of the proposals, and the due date for submitting amendments.

We first associate the sequences with the sections of the draft Constitution Treaty. Then, we count the number of proposed amendments for each sequence from the information published on the archival website of the Convention. ${ }^{5} \mathrm{We}$ include all amendments, including amendments with one or more authors as well as substantially similar amendments. Because amendments posted on the

\footnotetext{
${ }^{4}$ We thank Michael Laver for this suggestion.

${ }^{5}$ The proposed amendments can be accessed on the website of the European Convention (European Convention, 2003d).
} 
Convention website do not include a date, we cannot tell when exactly an amendment was proposed. We can thus only use aggregate data for the amendments. For each sequence, we count the number of words of the Praesidium proposal documents. To ensure that only the actual proposed constitutional text is coded, we do not count comments and/or explanations. We further code whether the Praesidium set a date for proposing amendments. This is an important control variable, because it potentially affects our conclusions whether timing of proposals was relevant in the European Convention. The Praesidium published only one document setting deadlines for proposing amendments. This document covers six out of the ten proposal sequences. ${ }^{6}$ In total, 6,043 amendments were proposed in the Convention. On average, members proposed 604 amendments for a proposal that was 6,100 words long. The time to submit amendments was on average one and a half weeks.

Figure 1 presents two time-series plots of the number of amendments and the length of the Praesidium proposals. Each point represents the date of a Praesidium proposal sequence (appendix A lists all sequences and proposals in detail). Whereas the proposals were presented between February and May 2003, the Praesidium had already presented in October 2002 an outline of what the structure of the Constitutional Treaty should look like. The Praesidium took therefore several months to draft its first actual constitutional proposal. ${ }^{7}$ During the first half of the drafting period, the Praesidium presented the proposals on the general first part and on the area of freedom, security and justice. By contrast, the institutional provisions and other specific policies were proposed during the second half of the drafting phase. The top plot shows that the peak of amendments was reached by the end of April 2003, when the Praesidium presented the institutions and foreign policy articles. Earlier and later proposals attracted fewer amendments. The bottom figure reveals that the length of the proposals ranged between 1,000 and 10,000 words, with one exception. At the very end, the Praesidium presented its longest proposal, which covered the detailed provisions on the policies (internal market, economic and monetary union, employment, social policies, agriculture and fisheries, environment, consumer protection, transport, research and energy). We conceive the length of a proposal as a measure for its 'amendability'. An alternative method would be to read the proposals and score them on the basis of their significance. However, such an approach would be open to different objections. For instance, readers might disagree about what constitutes an important proposal and which proposals may receive more amendments than others. Our approach is indifferent to the

\footnotetext{
${ }^{6}$ Indicative Programme of Work of the Praesidium (European Convention, 2003a).

${ }^{7}$ Preliminary Draft Constitutional Treaty (European Convention, 2002c).
} 
Figure 1: Number of Amendments and Praesidium Proposal Length
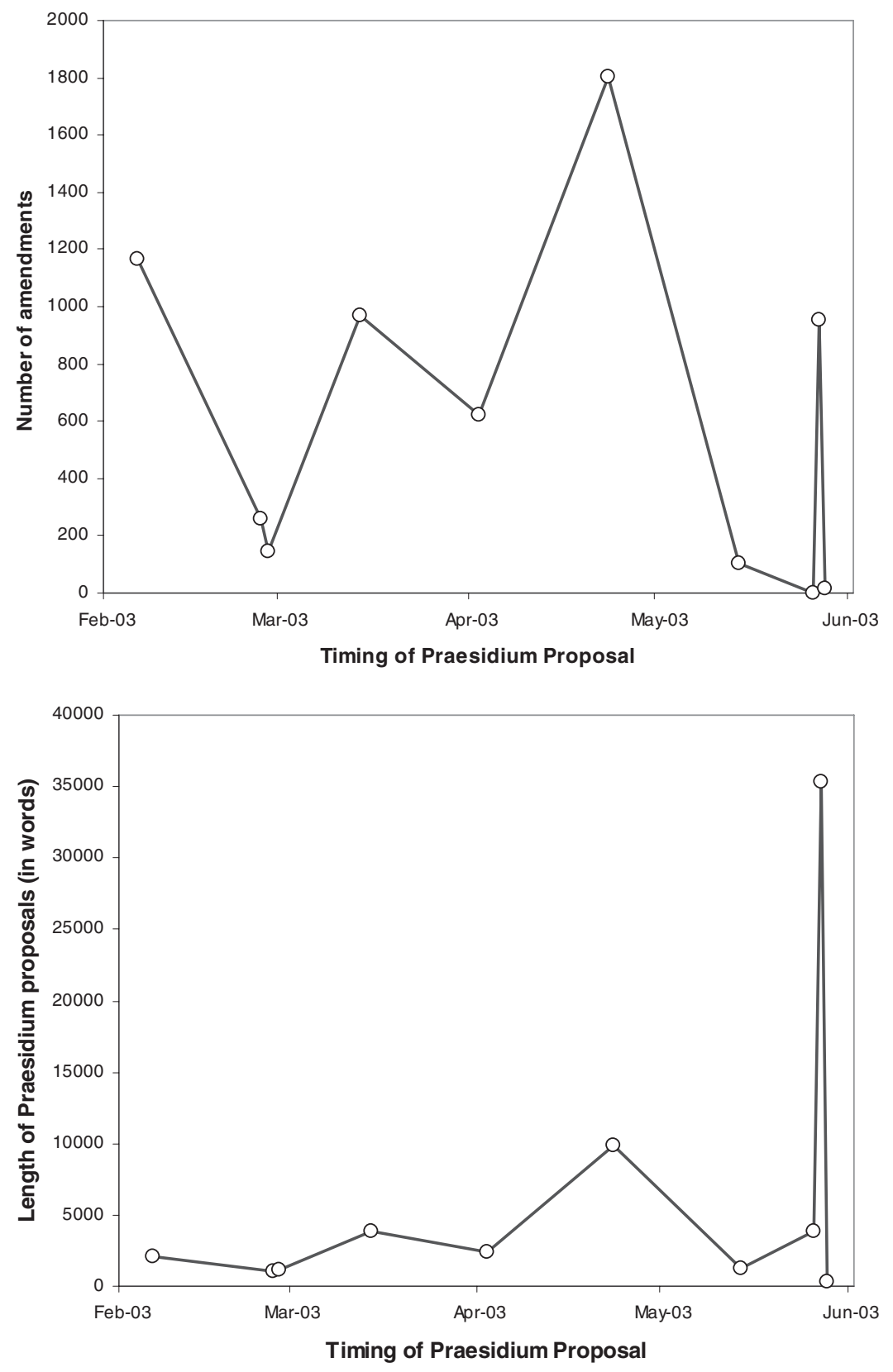

Source: Authors' own data. 
interpretation of the proposals, but simply assumes that more amendments can be proposed for longer proposals.

Only in combination, however, can the two variables (amendments and proposal length) provide an insight into the issue of timing. We therefore calculate the ratio of number of amendments to the length of the proposals. This controls for the fact that more comprehensive proposals are more 'amendable' than shorter ones. The ratio reflects more adequately whether timing had an effect on the number of proposed amendments. Figure 2 shows the time-series plot of this ratio. The most important observation is that the ratio declines over time. The later a proposal was presented to the Convention, the smaller the ratio of amendments to proposal length. Note that we showed earlier that - at least during the first six sequences - the members of the Convention had roughly the same amount of time to amend the proposals. The decline of the ratio is almost linear with a spike on the third sequence.

Figure 2: Ratio of Amendments to Praesidium Proposal Length

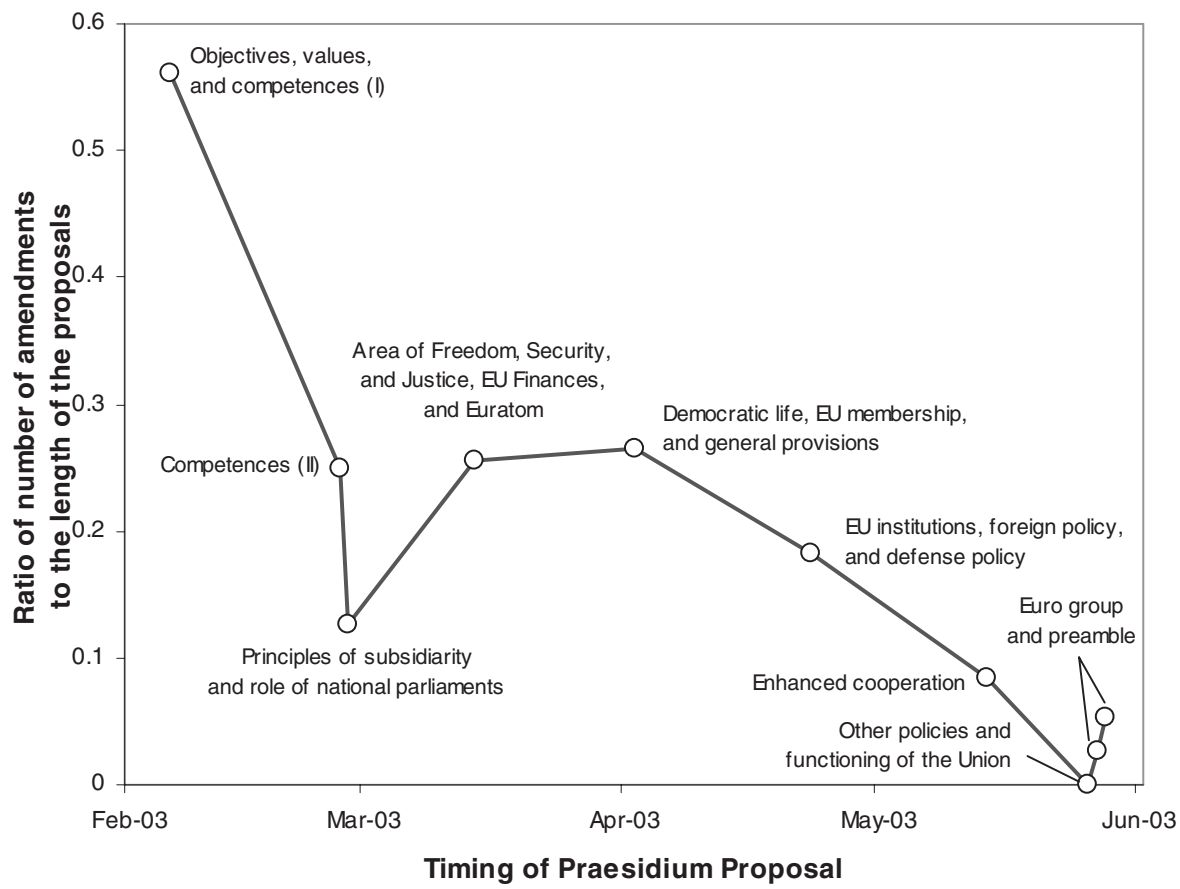

Source: Authors' own data. 
Which proposals were grouped together and, most importantly, why? Figure 2 shows that some, but not all, sequences followed the structure of the Constitutional Treaty. The first three sequences represent somewhat coherent proposals. The first and second sequence proposals are general introductory articles of the Constitutional Treaty. The third sequence dealt with the role of subsidiarity and national parliaments. The subsequent three sequences, however, were a mix of several topics.

Sequences four, five and six all included sections which did not belong together. The fourth sequence combined two policy areas (freedom, security and justice and the Euratom treaty) and the financial provisions; the fifth sequence democratic life, EU membership and general provisions; and finally the sixth sequence included proposals on institutions and foreign and defence policy. The last sequences introduced the remaining sections: enhanced co-operation, the protocol on the Eurogroup and the preamble. By far the longest proposals of the Praesidium were the provisions of 'other policies and the functioning of the Union'. This included the entire set of policies other than the area of freedom, security and justice and foreign and defence policy.

While we claim that significant proposals were delayed until the end, we cannot rule out the possibility that that the Praesidium did not propose them because it simply could not agree. Thus, we do not know whether holding back certain proposals was for strategic reasons only. We address this issue in a twofold manner. First, we show that sequences neither corresponded much to the outline of the Constitutional Treaty presented in October 2002 nor to the final Constitutional Treaty. Second, we provide anecdotal evidence that suggests that (at least) the Presidency was aware of the strategic aspect of timing.

To show that timing did not simply follow the outline of the constitution, we consider all sections of the final draft constitution. We code the rank order of each section in the (1) outline of the Constitutional Treaty presented in 2002 by the Praesidium, (2) the proposal sequences of the Praesidium and (3) the final draft constitution. We expect a high correlation between (1) and (3), but not between (1) and (2), and (2) and (3). The correlation results in Table 1 confirm our expectation. The Spearman rank-order correlation is very high for the outline and the final draft, but low for the outline and the timing of proposals and the draft Constitutional Treaty and the timing of proposals. In other words, the timing of the Praesidium proposals only weakly followed the outline and the final draft. Instead, the Praesidium combined different sections (e.g. sequences 3,6 ) or waited with important proposals until the end (e.g. sequences 6, 8 and 10).

Anecdotal evidence suggests that the Praesidium proposed important issues towards the end. The decision to split the work of the European 
Table 1: Outline, Proposals and Draft Constitutional Treaty - Spearman

Correlation Coefficients

\begin{tabular}{|c|c|c|c|}
\hline & $\begin{array}{l}\text { Proposed outline of } \\
\text { constitution }\end{array}$ & $\begin{array}{l}\text { Praesidium } \\
\text { proposals }\end{array}$ & $\begin{array}{l}\text { Final draft } \\
\text { constitution }\end{array}$ \\
\hline $\begin{array}{l}\text { Proposed outline of } \\
\text { constitution }\end{array}$ & 1 & & \\
\hline Praesidium proposals & $\begin{array}{c}.2991 \\
(p=.0964)\end{array}$ & 1 & \\
\hline Final draft constitution & $\begin{array}{c}.8396 \\
(p=.0000)\end{array}$ & $\begin{array}{c}.2480 \\
(p=.1711)\end{array}$ & 1 \\
\hline
\end{tabular}

Source: Authors' own data.

Note: $\mathrm{N}=32$ sections of the constitution. Statistical significance indicated in parentheses.

Convention into three general stages (a listening stage, a study stage, a proposal stage) encouraged general discussions about constitutional issues within the Convention, but discouraged concrete proposals, amendments and decisions. Some members of the Convention expressed their dissatisfaction with this procedure:

I have my doubts whether it is possible to debate the famous part III on policies in a satisfactory manner, simply due to the issue of timing. If we get this text on 30 May, then there must be a possibility of discussing and amending it, as we did with the other parts [...]. Part III is not a technical part, but highly political, in certain respects even more so than the first part.

Elmar Brok (MEP), 15 May 2003, Plenary Session of the Convention (European Convention, 2003c)

I would still say that it is a pity that we have not also devoted our agenda today to a discussion about the institutional questions. The Convention has not devoted enough time to this in its discussions.

Jari Vilén (Parl., Finland), 5 June 2003, Plenary Session of the Convention (European Convention, 2003c)

We have left the institutions to the very last minute.

Dick Roche (Gov., Ireland), 5 June 2003, Plenary Session of the Convention (European Convention, 2003c)

We made the argument that lack of time shifted the balance of power towards the Praesidium. The quoted statements indicate that there was strong resentment of these procedural manoeuvres among the Convention delegates. Institutions and the definition of the legislative procedures for the policies constituted significant parts of the Constitutional Treaty. 


\section{Changing the Rules of Procedure}

After the Praesidium had presented a complete draft of the European Constitutional Treaty, the Presidency changed the amendment rules of the Convention. The Presidency changed this rule in a twofold manner. First, it considered the component groups of the Convention to be the only legitimate actors to submit amendments during the final phase of the revisions. The component groups were the representatives from national parliaments, Member State governments, the European Parliament and the European Commission. Second, the President stated during the plenary session of 11 June 2003 that only amendments that had unanimous approval within the component groups would be considered. Giscard said:

We will not restart the general discussion of the text, in particular about amendments which have already been submitted and which have been discussed and either been accepted or not [...] With regard to all these subjects, I have said that we [the Praesidium] will treat them if there are joint proposals [of the component groups] following your work. We will not reopen the debates on our own. These debates have been concluded. If there are joint proposals, then we will consider them. If there are not [...] the problem will remain in its current state.

Giscard d'Estaing, 11 June 2003, Plenary Session of the European Convention (European Convention, 2003c)

There are reports that this rule was in fact applied, when the representative from the Praesidium Amato met with the representatives of Member State governments. An amendment which reflected the support of 18 governments was not considered on the basis that unanimity was absent in the component group (Norman, 2003, p. 291). On 4 July 2003, Giscard furthermore limited the amendment possibility to the important third part of the Constitutional Treaty (policies and functioning of the Union). Giscard said that only amendments would be accepted which did not threaten the consensus reached on 13 June over the first and second party of the constitution. He specified:

It is clear that this is not the general reopening of the debate, that the framework of [the European Council in] Thessaloniki is precise and also legitimate. We can therefore not accept amendments which digress or which make the realization of the consensus, which we have reached for parts I and II, more difficult. The amendments must remain in the logic of this consensus, and therefore we need to exercise a bit of self discipline.

Giscard d'Estaing, 4 July 2003, Plenary Session of the European Convention (European Convention, 2003c) 
Formally changing the rules of procedure constitutes a powerful way of limiting the number of amendments. The likelihood that there was less opposition from the floor to such a rule change is higher towards the end of the Convention. The Praesidium did not do this rule change until the very end and it did not affect many issues. However, it is an additional important point that emphasizes that the Presidency used a range of feasible rule manipulations.

\section{Selecting and Amending Amendments}

Limiting the number of amendments was one strategy of the Praesidium and the Presidency to increase agenda control. The other strategy was to couple and juxtapose amendments so that the initial Praesidium proposal would represent the best alternative. But even if amendments were successful, the Presidency ensured that those amendments could be amended again by another Praesidium proposal. Through an iterated agenda-setting procedure, the final outcome would be located closer to the positions of the Praesidium or Presidency than to the Convention members who had proposed an amendment. We outline the two strategies (juxtaposing amendments and iterated agenda-setting) and demonstrate their effect on the outcome of the Convention.

\section{Juxtaposing Amendments}

One particular method used by the Presidency to select amendments was to conclude consensus on issues, even if the criteria for doing so would remain unclear. The President would juxtapose several proposed amendments and conclude that the Praesidium proposals represented the best alternative.

The article of enhanced co-operation in the European Union attracted some amendments, in particular over the issue of the minimum threshold of participating Member States. Enhanced co-operation was thought to constitute a last resort if some Member States wanted to deepen their co-operation in a particular policy area. The Treaty of Nice had set the minimum number to eight Member States, which back in 2000 constituted a majority of the Member States. In the plenary debate of 5 June, Giscard presented the issue as follows:

Concerning the issue of enhanced co-operation [between Member States], we propose to set the minimum participation to eight Member States, which had been fixed in the Treaty of Nice, and which pleases a certain number of you. Others demanded that we set this number lower, others demanded that we set it higher. In the end, we keep the number at eight. 
Giscard d'Estaing, 5 June 2003, Plenary Session of the European Convention (European Convention, 2003c)

Contrary to what Giscard said here, the Praesidium actually did not stick with the Nice status quo, because at the time of the Convention a threshold of eight actually meant that less than a third of the Member States was necessary to initiate enhanced co-operation.

A similar trick was used in a previous plenary session, when the Convention discussed the proposals and amendments on the institutions. On 15 May 2003, President Giscard summarized the amendments on institutions, which gave him the most discretion as to what amendments to accept or reject. $\mathrm{He}$ noted that there were essentially two types of amendments related to the institutional proposals. The first type were supposed to be the most numerous and "most important, which did not call into question the overall architecture of the draft submitted by the Praesidium. They were intended to clarify the proposed revisions' (European Convention, 2003b). He characterized the second type of amendments as fewer in number, yet significant, which demanded to maintain the status quo. He went on to wonder 'whether such a status quo approach was compatible with the mandate which the Convention had received at Laeken' (Summary of plenary meeting on 15 May 2003, CONV 748/03, p. 3). Giscard reiterated the mandate given to the Convention by the Laeken European Council:

First question: how can we increase the democratic legitimacy and the transparency of the three current institutions? Second question: how can we reinforce the authority and efficiency of the European Commission which proves well that we can not be satisfied with the current situation? And third question: can we keep the six month rotation of the Council? Your amendments must respond to these questions of Laeken and it is a matter of fact that the group of amendments which insists on retention of the current system obviously does not respond to the Laeken questions.

Giscard d'Estaing, 15 May 2003, Plenary Session of the European Convention (European Convention, 2003c)

Giscard juxtaposed the amendments, but disqualified one side on arbitrary grounds that they would not respond to the mandate of the Convention. The remaining amendments overall would support the Convention.

Because the amendment process was controlled by the Praesidium and the Presidency, Giscard did signal to the Convention that the Praesidium would take proposed amendments seriously. For instance, he would occasionally point out that the Praesidium responded to the amendments. In the following 
example, however, the criteria for what the Praesidium would consider remained unclear:

Six of you demanded the deletion of the article on voluntary withdrawal from the Union. We have reformulated the proposal according to your amendments.

Giscard d'Estaing, 5 June 2003, Plenary Session of the European Convention (European Convention, 2003c)

While six members of the Convention were sufficient to make the Praesidium revise its proposal, a comparable number of supporters were not in other instances, demonstrated above.

Another example of signalling was Giscard's sacrifice of his personal idea of a 'Congress of the EU', a new institution composed of MEPs and national parliamentarians. Giscard described the deletion of the corresponding articles as a response by the Praesidium to demands by the Convention. The idea of a Congress could very well have constituted extra bargaining power, to be dropped if necessary (Norman, 2003, pp. 348-49).

You have seen that the article on the Congress disappeared because it seems that a big number among you was not favourable to this idea. I simply attract the attention of those members [...], which want, out of malice or not, to pretend that I do not listen to their arguments. [. . .] This article to which I particularly adhered [...] does not appear in the texts which have been distributed to you.

Giscard d'Estaing, 5 June 2003, Plenary Session of the European Convention (European Convention, 2003c)

We have so far identified cases in which the Presidency coupled and juxtaposed amendments so that they do not matter. However, this strategy is dependent on the nature of the amendment. For instance, it is easier to pursue this strategy if only a limited number of members endorsed the amendments or if the issue salience is low. Therefore, we would expect that there will be amendments which will be successful. In this case, however, the Presidency of the Convention could revert to an iterated process which enabled the Praesidium to modify successful amendments.

\section{Iterated Agenda-Setting}

The comparison between the one shot and the iterated agenda-setting game leads to systematic influences of iterated agenda-setting as opposed to failure or random amendments prevailing in a one shot game. In the latter, the agenda-setter makes a proposal which is amended, accepted or rejected by 
the floor. The approach assumes that there are procedures in place which determine which amendments eventually prevail (e.g. amendments with the largest support coalition). Due to the absence of an amendment procedure in the European Convention, a one shot agenda-setting game could have resulted in either failure (no amendments get accepted) or in the modification of the proposed amendments and the acceptance of constitutional provisions by different majorities. Through iteration, however, the Presidency guaranteed a systematic influence on outcomes. The procedure is outlined as an agenda tree in Figure 3.

First, the Presidency (Giscard d'Estaing) decides whether to propose a particular constitutional article. This proposal is first made to the Praesidium, which votes on the proposal. Then, this proposal is submitted to the members

Figure 3: Iterated Agenda-Setting in the EU Convention

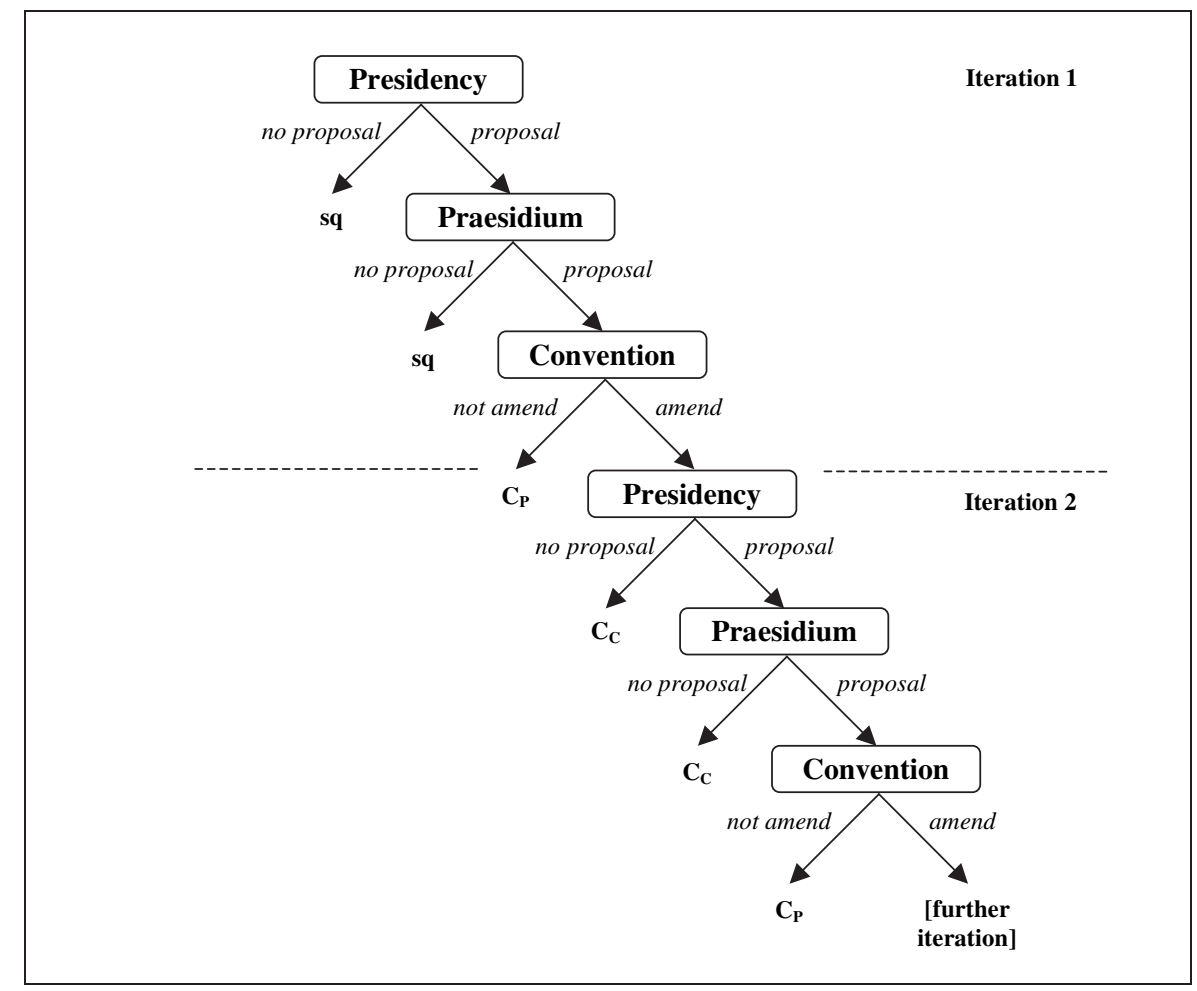

Notes: $\mathrm{sq}=$ constitutional status quo; $\mathrm{C}_{\mathrm{P}}=$ constitutional article or sets of articles proposed by the Praesidium and the Presidency of the Convention; $\mathrm{C}_{\mathrm{C}}=$ Praesidium proposal amended by one or more members of the Convention. 
of the Convention, who have the opportunity to propose amendments. Thus, the apparent conflict is between the Praesidium (proposal) and the Convention (amendments). But it is the Presidency which can decide to retain amendments or to reiterate (i.e. re-propose) its proposal to the Praesidium (or a slight modification thereof). This proposal then goes back to the Convention floor, which has another possibility to amend it. The Presidency controls the procedure by being able to iterate the proposal/amendment round until an outcome is reached that is satisfactory to it.

Figure 4 shows the effects of iterated agenda-setting. Assume for now that President Giscard d'Estaing $(G)$ took a central position in a two-dimensional issue space. There are four members of the Convention (A, B, C and D) and, for simplicity, we assume that decisions require the support of a majority (3/5). If the President proposes his own position G, it can be amended by proposal $\mathrm{G}^{\prime}$. Through iteration this amended proposal can be amended back to $G^{\prime \prime}$ and still enjoy majority support. While the proposal $\mathrm{G}^{\prime}$ is far away from the preferences of Giscard, the alternative proposal $G^{\prime \prime}$ brings the final outcome close to the President's preferences. Our analysis of the Praesidium proposals supports the claim of iterated agenda-setting. The table in appendix A lists all sequences of the Praesidium proposal as well as the number of amendments and how often the Praesidium re-proposed a particular section of the Constitutional Treaty. The last column in the table shows that the

Figure 4: Effect of Iterated Agenda-Setting

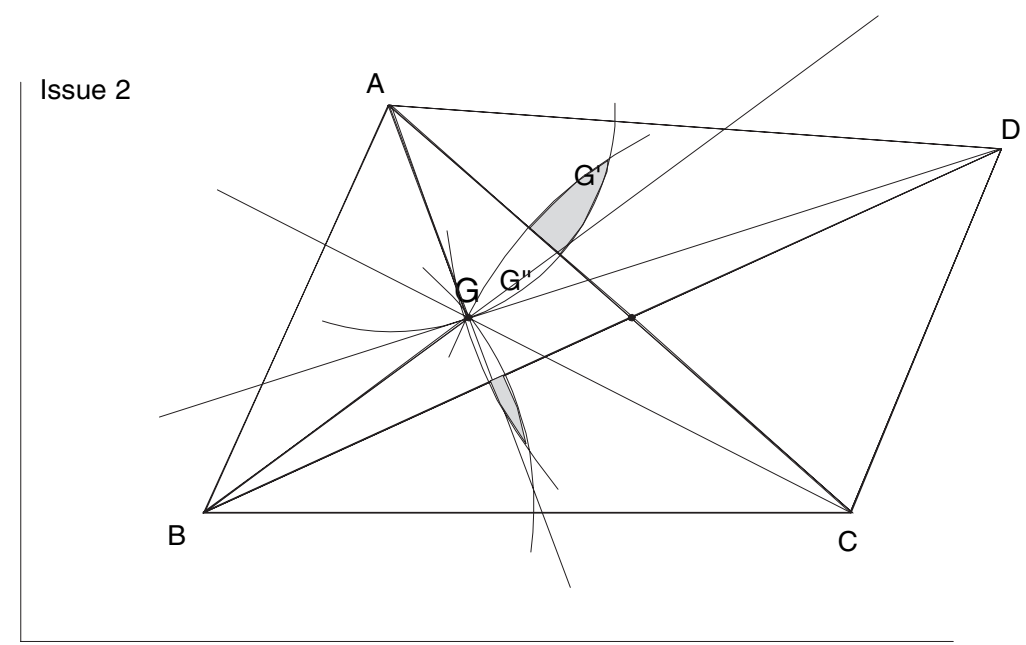

Issue 1 
Praesidium re-proposed its proposals at least twice in almost all instances. The sections that were revised the most often were the EU's external action (five times), economic and monetary policy (four times), competences, area of freedom, security and justice, other specific areas, and institutions (all three times).

Giscard's ability to extract as much as possible from the Convention depends on two factors: his own position and the set of feasible alternatives. Figure 5 shows the effects of both. Assume that the Convention can either be homogenous or heterogeneous. A homogeneous Convention would be able to adopt any constitutional proposal in win-set 1 (quadrangle), whereas a heterogeneous Convention would be able to adopt a proposal in the smaller win-set 2 (triangle). Suppose Giscard can have one of three possible positions, labelled G1, G2 and G3. The first position is located outside both win-sets, the second position is contained in the large win-set but not in the small one, and the third position is inside both. In all cases Giscard has more influence if the win-set is larger. If he is located in G1, his proposal would be located at G11 compared to G12 given the smaller one. If he is located at G2, he in fact can propose his own position G21 given a large win-set and G22 for the smaller one. Finally, if he is inside both win-sets,

Figure 5: Giscard's Influence as a Function of the Heterogeneity of Convention Delegates

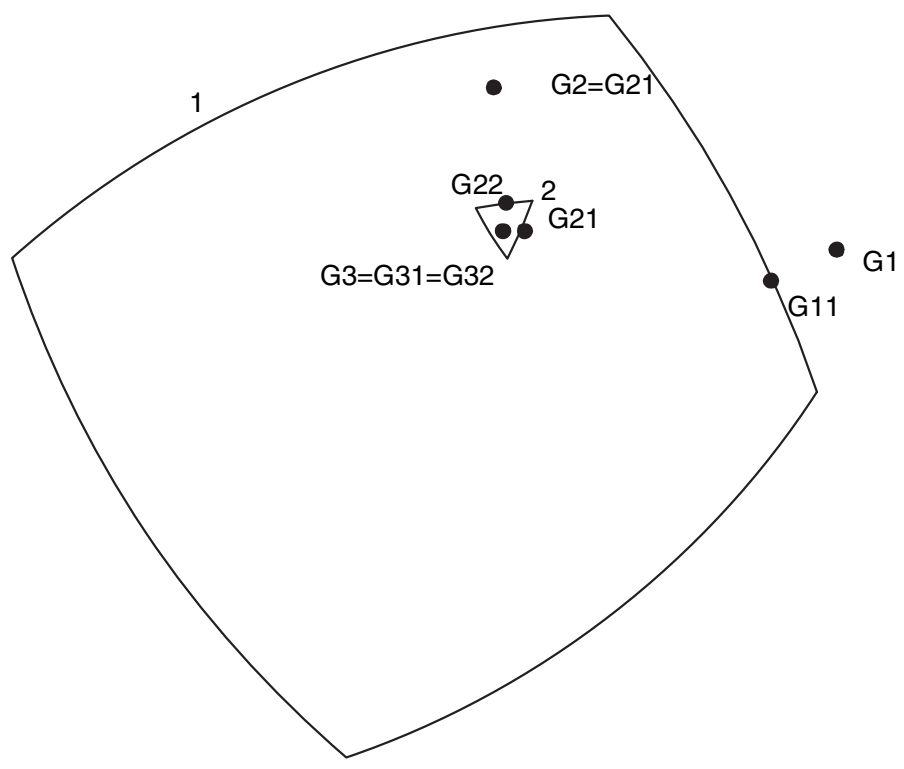

(C) 2007 The Author(s)

Journal compilation (C) 2007 Blackwell Publishing Ltd 
his proposals are identical to his position G3. The implications of this analysis are that Giscard will make substantively similar proposals if the win-set is small. The point that Giscard can do whatever he wants assumes the larger win-set 1. Although both scenarios are feasible, we believe that the former is more likely because the Convention included more players with more diverging preferences than are usually represented at Intergovernmental Conferences. ${ }^{8}$

\section{Absence of Voting}

It is important to note that everything we have stated so far about agenda control, limiting and selecting amendments is true for any type of voting rule, unanimity or majority voting. The Convention, however, did not vote on proposals, amendments, or on the final constitution. Decisions were made by 'consensus' and it was the interpretation of consensus that gave the Presidency even stronger agenda control of the process.

The mandate of the European Council to the Convention only specified that an outcome should be reached by consensus. This gave the agendasetting presidency leeway to conclude meetings according to its liking. In the beginning of the work of the Convention, the Praesidium decided that voting would not be an alternative as a working method:

Members of the Praesidium recognised that, given the non-homogenous character of the composition of the Convention, it was not appropriate to resort to a vote. The Convention should aim at achieving consensus or, at least, a substantial majority.

Praesidium meeting conclusions, 22 February 2002 (European Convention, 2003c)

The Convention rules of procedure stipulated for the outcome to be adopted by consensus, without the possibility of indicative votes. It was up for the President of the Convention to determine what consensus meant. In practice, a typical Convention day proceeded as follows: the members of the Convention would put their names on the list of speakers and would thus be able to speak for a few minutes in the plenary on the subject matter on the agenda. Giscard would conclude the session pointing out those points that according to his view were accepted by consensus (Deloche-Gaudez, 2003, p. 394). The President explicitly stated that his role was an agenda-setter of a constitutional convention, comparing it with the situation of the Federal Convention of the United States:

\footnotetext{
${ }^{8}$ We thank one of the anonymous reviewers for pointing this out.
} 
I tried to play a little bit the role that Jefferson played, which was to instil leading ideas into the system. Jefferson was a man who wrote and produced elements that consolidated the Constitution.

President Giscard d'Estaing, as quoted by the New York Times, 15 June 2003 (New York Times, 2003)

The Vice-President of the Convention, Giuliano Amato, summarized how President Giscard d'Estaing would use his summaries to determine consensus even if there was none. He would listen to sharply dissenting views and then say:

'Well I understand there are views on one side and views on the other, but on the whole the idea is accepted.' [Giscard d'Estaing] was, Mr. Amato added, 'Flying on his own wings, and these qualities tend to be disturbing to others.'

Giuliano Amato on Giscard d'Estaing, as quoted in the New York Times, 15 June 2003 (New York Times, 2003)

The Presidency furthermore resisted changing the rule of consensus. During the plenary session on 16 May 2003, a Convention member demanded that votes should be held on major topics of the Convention, otherwise it would become 'impossible to conclude what the consensus should be', adding that 'otherwise it will be very frustrating at the end to see [that none of the] amendments have been taken on board at all' (Convention, 2003c). Concerns that the Presidency and the Praesidium would use the procedure to keep a tight control over the agenda were thus voiced in the Convention. In response, President Giscard d'Estaing rejected those demands:

The Convention does not vote and for a simple reason: its composition does not allow it. There are two representatives from the Commission. The Commission will not have 2 out of 105 votes. That would not make sense. There is the group of national parliamentarians which is three times greater than the group of members from the European Parliament. We will not have the one oppose the other. Therefore, we will not vote and have to find a consensus. This will naturally become more delicate during the final phase, but that is our rule. We have noted the interventions and we have seen, for example, that there are more interventions to get rid of the rotating presidency [of the Council] than to keep it. We will see in the final phase what the consensus is.

President of the Convention Giscard d'Estaing, Plenary Session, 16 May 2003

In sum, the absence of voting reinforced the Presidency's agenda control which included limiting the number of amendments to its proposals and selecting amendments which it deemed favourable. 


\section{Conclusion}

The constitutional text produced by the European Convention was slightly modified at the IGC in Brussels and became the draft Constitutional Treaty of the EU. It underwent ratification in most of the countries. Some of them used their parliaments for that purpose, others held referendums. A third group of countries has not yet ratified. ${ }^{9}$ All of the parliamentary ratifications were overwhelming. The referendums had very different results. ${ }^{10}$ While voters in Luxembourg and Spain accepted the new Constitutional Treaty, France and the Netherlands rejected it. These negative votes threw the process into disarray. It is not clear what the next steps will be. The EU has declared a period of reflection and presumably after the end of this period France and the Netherlands will have to explain the meaning of their negative votes. In other words: what should be included or excluded from the Constitutional Treaty for it to be acceptable by each one of these countries.

This convoluted process highlights two questions: first, why do political elites have a different attitude than masses towards the EU Constitutional Treaty? Second, how was the adoption of the Constitutional Treaty worked out so smoothly, while the ratification process got derailed? The answers to both these questions are related.

First, the difference between elites and masses in their response towards the Constitutional Treaty can be explained by reference to the reversion point. The constitutional process specifies that whenever an agreement cannot be reached, the European Union reverts to the previous ratified agreement. This statement implies that if the EU Constitutional Treaty is not adopted, the EU reverts to the Nice Treaty. This outcome has been unacceptable for European elites for quite a while. This is the reason for the decision to move to a constitutional convention. The Nice Treaty rules along with the expansion of the EU to 27 countries would make political decision-making next to impossible in the EU. This is the reason why the process of revision was initiated and concluded among elites. However, the masses had a different point of view. Whether it was fear of foreigners or bureaucracies (both France and the Netherlands), or inflationary currency (Netherlands) or fear of weakening of the welfare state (France), the masses were rejecting the EU Constitutional

\footnotetext{
${ }^{9}$ As of May 2006, ratifications took place in parliaments in Austria, Belgium, Cyprus, Estonia, Germany, Greece, Hungary, Italy, Latvia, Lithuania, Malta, Slovakia, Slovenia. Referendums took place in France, Luxembourg, Netherlands, Spain. Countries that have not yet ratified: Czech Republic, Denmark, Finland, Ireland, Poland, Portugal, Sweden, United Kingdom.

${ }^{10}$ Actually, there is a history of elites being unified around the issue of European integration and publics divided (Ireland had to repeat its referendum to accept the treaty of Nice, France had a very divisive referendum to accept the Treaty of Maastricht).
} 
Treaty not because of a comparison with the alternative (the Nice Treaty), but because of consequences irrelevant to the Constitutional Treaty. Indeed, adoption or rejection of the Constitutional Treaty has no effect on inflation, or foreigners or the welfare state. It does have an impact on bureaucracies (Yataganas and Tsebelis, 2005), but exactly in the opposite from the feared direction. It is the rejection of the Constitutional Treaty that is more likely to lead to more bureaucracy. So, it is the lack of comparison of the effects of the Constitutional Treaty at the level of the masses that most likely generated the negative referendum outcomes.

Strange as it may seem, the answer to the second question, why the Constitutional Treaty got adopted painlessly but cannot get ratified, is to a large extent the same. It is precisely because elites were aware of the alternative that they were eager to adopt a new Constitutional Treaty. What this study points out is that in addition to this understanding that agreement was imperative, the European Convention came to a conclusion because the Praesidium under the leadership of Giscard had a unified conception and exercised all its agenda-setting powers: the ones attributed to them by the Convention mandate as well as the ones generated on their own through the procedures (the elimination of amendments, the iterated agenda-setting process and the absence of voting).

Understanding that the adoption of a Constitutional Treaty was an exceptional event made possible by the combination of a very creative, consistent and overpowering agenda-setting process and the impasse created by the status quo (Nice Treaty) explains how we came to an EU Constitutional Treaty, and how difficult it will be to move away from the current document. And this realization may be helpful when Europeans start contemplating if there is an alternative Constitutional Treaty and how it could be generated.

\section{Correspondence:}

George Tsebelis

Department of Political Science

University of California, Los Angeles

4289 Bunche Hall

Los Angeles, CA 90095, USA

e-mail: tsebelis@ucla.edu 


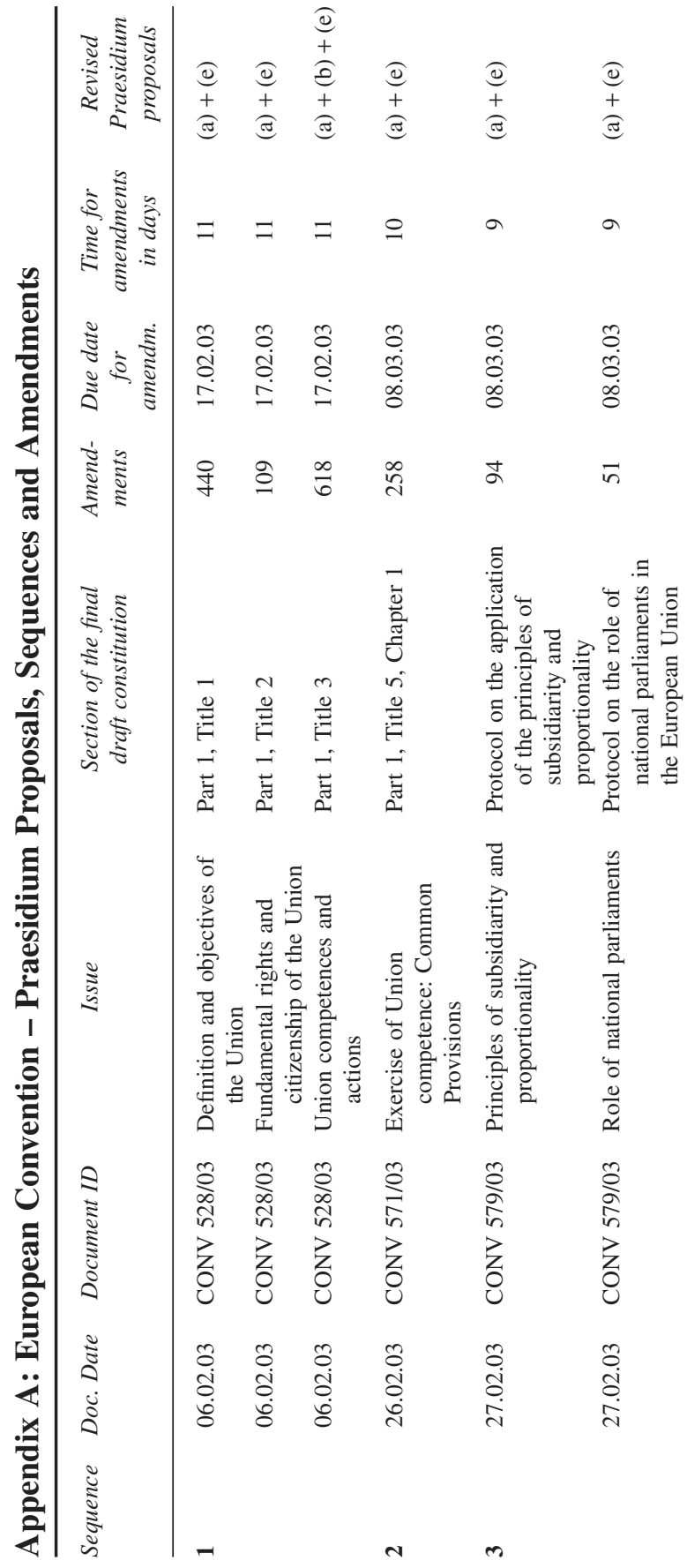




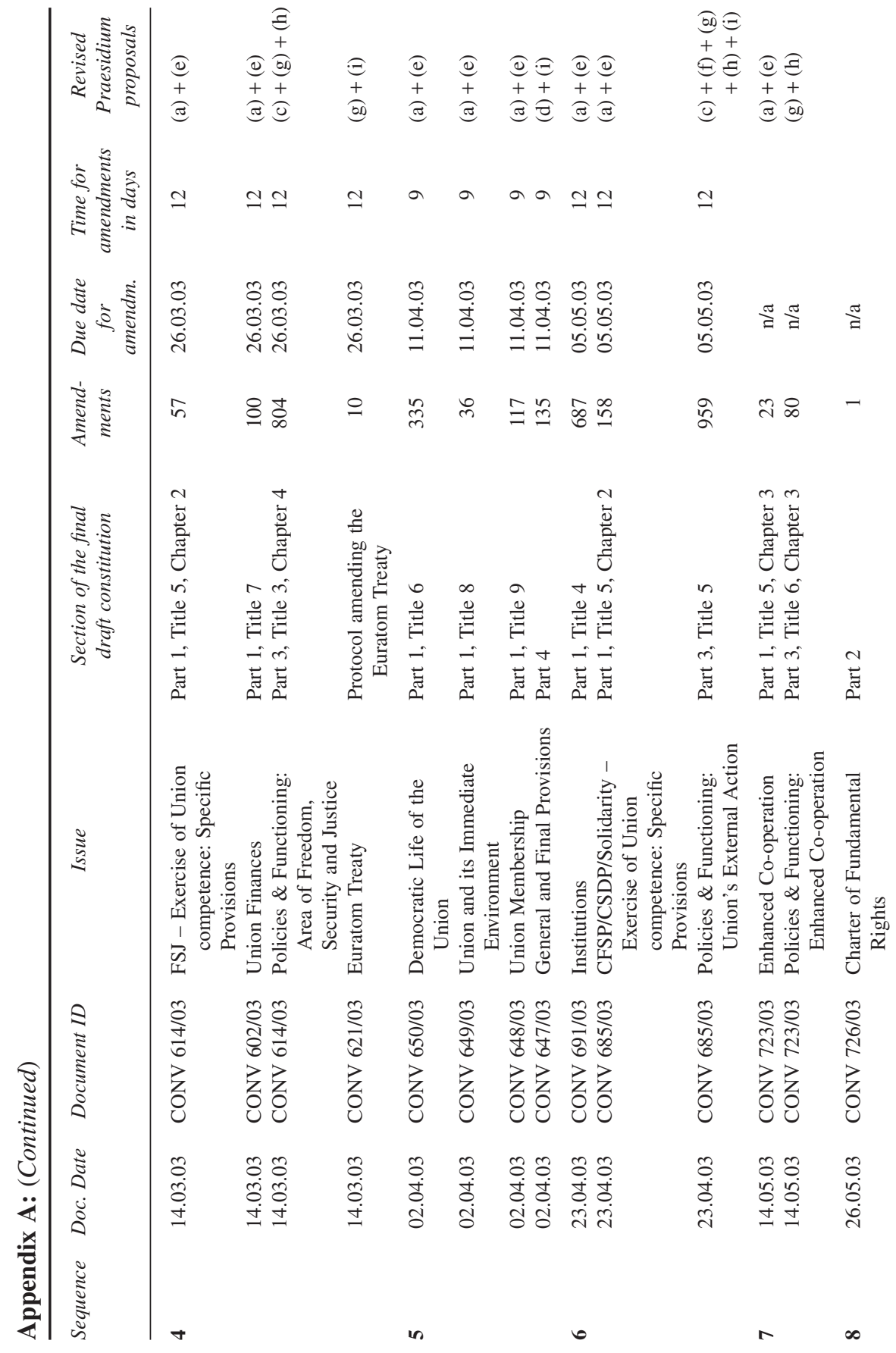

(C) 2007 The Author(s) 


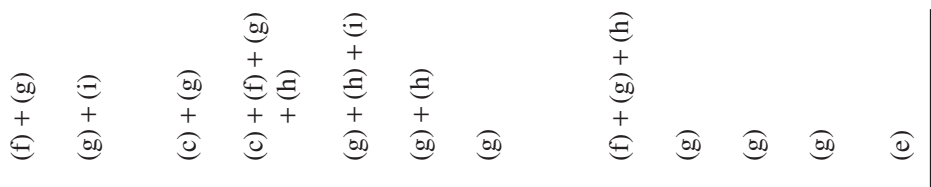

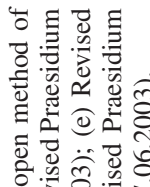

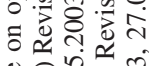

可它 $\Theta$

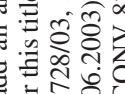

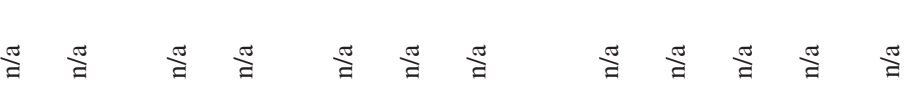

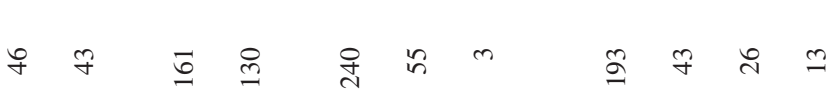

$\infty$

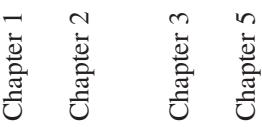

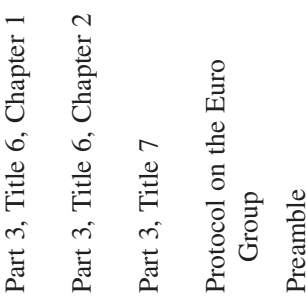

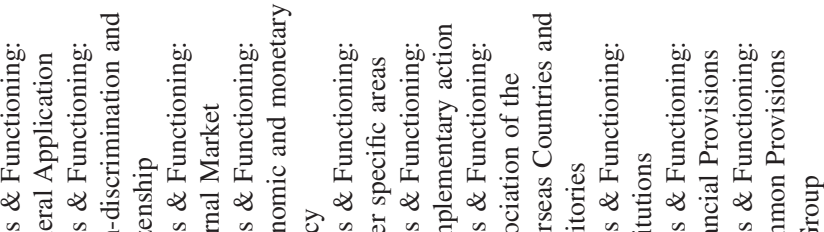

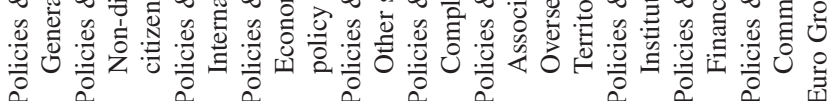

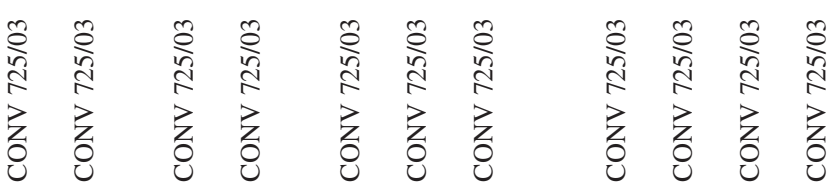

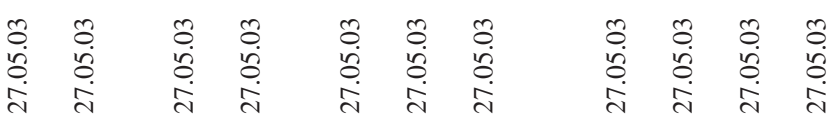

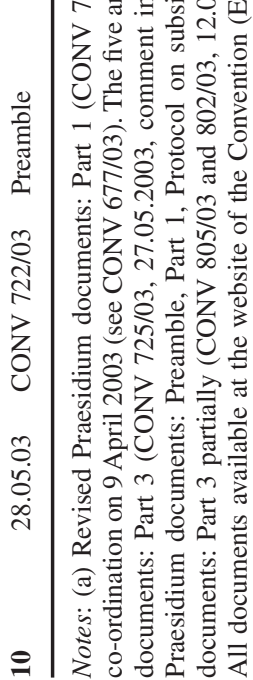




\section{Appendix B: Excerpts from the Rules of Procedure of the European Convention}

Source: (Convention doc. 9/02 from 14/03/2002)

Article 1: Notice of Meetings

The Convention shall be convened by its Chairman with the agreement of the Praesidium or following a written request by a significant number of members of the Convention.

\section{Article 2: Calendar and Agenda}

The Praesidium shall draw up the provisional calendar and agendas for meetings of the Convention and shall submit them to the Convention for approval. Any member of the Convention may ask the Praesidium in writing to add agenda points to the draft agenda of a Convention session. The Praesidium shall in any case add a subject to the draft agenda when the request is made by writing one week before the scheduled session of the Convention by a significant number of members. At the beginning of a meeting, the Convention may decide by consensus on a proposal of its Praesidium to add other items to the agenda.

Article 4: Written Contributions

1. Any member (full or alternate) and observer of the Convention may address a written contribution to the Praesidium. The contributions may be individual or collective.

2. Such written contributions shall be forwarded to the members (full and alternate), and observers of the Convention by the Secretariat and shall be available on the Convention website.

Article 6: Conduct of Meetings

1. Meetings of the Convention shall be chaired by the Chairman of the Convention or in his absence by one of the two Vice-Chairmen.

2. The meetings of the Convention shall be held in the 11 languages of the European Union with simultaneous interpretation.

3. The representatives of the candidate States shall participate fully in the work and deliberations of the Convention.

4. The recommendations of the Convention shall be adopted by consensus, without the representatives of candidate States being able to prevent it. When the deliberations of the Convention result in several different options, the support obtained by each option may be indicated. 
5. Any procedural questions relating to the conduct of meetings may be referred to the Praesidium; it will make a decision under the conditions which it has determined in accordance with paragraph 8 .

6. The Secretariat shall draw up the list of (full and alternate) members and observers present at each meeting of the Convention.

7. Taking account of views expressed by members of the Convention, the Chairman shall ensure the proper conduct of discussions, including by arranging as far as possible that the diversity of the Convention's views is reflected in the debates. He may propose to limit interventions in the interest of the efficient conduct of debates. He shall be assisted by the Vice-Chairmen and the Secretariat.

8. The meetings of the Praesidium shall be chaired by the Chairman or in his absence by one of the two Vice-Chairmen. The Praesidium shall decide on its working methods, acting on a proposal from the Chairman.

Article 11: Secretariat

The Convention Secretariat shall be directed by a Secretary-General. He shall take all necessary steps to ensure the proper functioning of the Convention.

Article 15: Working groups

In the light of views expressed in the Convention, the Chairman or a significant number of the members of the Convention may recommend that the Praesidium set up Convention Working Groups. The Praesidium will determine their mandate, working arrangements and composition, taking into account the specific expertise of members, alternates and observers in relation to the subject under discussion. Every member of the Convention may attend all such meetings. The Secretariat establishes a summary note after each meeting of the working groups.

Article 16: Revisions

The provisions of this Note may be amended or expanded by the Convention on a written proposal from the Praesidium or by a written request from a significant number of members.

\section{References}

Crum, B. (2004) 'Politics and Power in the European Convention'. Politics, Vol. 24, No. 1, pp. 1-11.

Deloche-Gaudez, F. (2003) 'La Présidence de la Convention Européenne'. Annuaire Français de Relations Internationales, Vol. 4, pp. 390-404. 
European Convention (2002a) First informal meeting of the Praesidium on 22 February 2002. Available at: «http://european-convention.eu.int/Docs/ praesidium/2002/020222.S.pdf», last consulted in January 2007.

European Convention (2002b) Rules of Procedure. 14 March 2002. Available at: «http://register.consilium.eu.int/pdf/en/02/cv00/00009en2.pdf», last consulted in January 2007.

European Convention (2002c) Preliminary Draft Constitutional Treaty. 28 October 2002. Available at: «http://register.consilium.eu.int/pdf/en/02/cv00/ 00369en2.pdf», last consulted in January 2007.

European Convention (2003a) Indicative Programme of Work established by the Praesidium of the European Convention. 27 February 2003. Available at: «http:// register.consilium.eu.int/pdf/en/03/cv00/cv00586en03.pdf», last consulted in January 2007.

European Convention (2003b) Summary of Plenary Meeting on 15 May 2003. Available at: «http://register.consilium.eu.int/pdf/en/03/cv00/cv00748en03.pdf», last consulted in January 2007.

European Convention (2003c) Verbatim Reports of Proceedings of the Convention's plenary session. Available at: «http://www.europarl.eu.int/Europe2004/ index_en.htm», last consulted in January 2007.

European Convention (2003d) Proposed Amendments to the Text of the Articles of the Treaty Establishing a Constitution for Europe. Available at: «http://europeanconvention.eu.int/amendemTrait.asp?lang=EN», last consulted in January 2007.

European Convention (2003e) Praesidium Documents. Available at: «http:// european-convention.eu.int/search.asp?lang=EN», last consulted in January 2007.

European Council (2001) Laeken Declaration on the Future of the European Union. Available at: «http://european-convention.eu.int/pdf/LKNEN.pdf», last consulted in January 2007.

Magnette, P. and Nicolaidis, K. (2004) 'The European Convention: Bargaining in the Shadow of Rhetoric'. West European Politics, Vol. 27, No. 3, pp. 381-404.

New York Times (2003) 'United Europe's Jefferson? Giscard d'Estaing Smiles'. 15 June, p. 6.

Norman, P. (2003) The Accidental Constitution: The Story of the European Convention (Brussels: EuroComment).

Tsebelis, G. (2005) 'Agenda Setting in the EU Constitution'. Paper presented at the Domestic Structures and European Integration Conference, Brussels 2005.

Tsebelis, G. and Yataganas, X. (2002) 'Veto Players and Decision-Making in the EU after Nice: Policy Stability and Bureaucratic/Judicial Discretion'. Journal of Common Market Studies, Vol. 40, No. 2, pp. 283-307.

Yataganas, X. and Tsebelis, G. (2005) 'The Treaty of Nice, the Convention Draft and the Constitution for Europe Under a Veto Players Analysis'. European Constitutional Law Review, Vol. 1, No. 3, pp. 429-51. 